\title{
A Bibliometric Analysis and Visualisation of Research Trends in Allergy of Steel- implants
}

\author{
Nishant Ranjan ${ }^{\mathrm{a}}$ \\ Department of Mechanical Engineering, Chandigarh University, \\ Gharuan,Punjab,India. 140413
}

Article History: Received: 11 January 2021; Accepted: 27 February 2021; Published online: 5 April 2021

\begin{abstract}
Steel is one of the most used metals for implants. The bibliometric analysis had been conducted to understand the active authors, organizations, journals, and countries involved in the research domain of "Allergy of steel-implants". All published articles related to "Allergy of steel-implants" from "Scopus", were analyzed using the VOS viewer to develop analysis tables and visualization maps. This article had set the objective to consolidate the scientific literature regarding "Allergy of steelimplants" and also to find out the trends related to the same. The most active journals in this research domain were the Contact Dermatitis, Injury, and Journal of Paediatric Surgery. The most active country was the United States of America. The leading organization engaged in the research regarding allergy of steel-implants were University Hospital in Munich and LudwigMaximilian University of Germany. The most active authors who had made valuable contributions related to the allergy of steel implants were Summer B. and Thomas P.
\end{abstract}

Keywords: Allergy, Steel-implants, Material engineering, Bibliometric analysis, VOS viewer,

\section{Introduction}

An engineered medical device to replace a missing or damaged biological structure is known as an implant. Different types of metals and materials are used to create implants and the most popularly used metals and alloys for bio-implants are stainless steel, cobalt-chromium alloy, and Titanium [1]. Various types of implants had been used in modern medicine and include sensory implants, neurological implants, cardiovascular implants, orthopedic implants, contraceptive implants, and cosmetic implants. Stainless steel is used for diversified implanting devices allergy and corrosion are serious challenges associated with stainless steel implants [2]-[5]. The allergy to metal implants is a serious issue to be addressed. Safety of material used is an important determinant while choosing implants and Stainless steel is a comparatively s safe metal used for implants. Material engineering and surface engineering can play a significant role in improving safety and reducing allergies associated with steel implants.

Stainless steel is often considered a safe metal for hip implants in comparison with Nickel [6]. Similarly, the blood nickel content can be reduced and serious complications like hypernickelemia can be avoided [7]. Stainless steel is not having high-class anticorrosive properties [8] and there are cases of implant failure due to corrosion of stainless steel [9]. Bacterial infection of implants can be a cause for allergy and failure of steel implants. Bacterial infection of steel implants can be mitigated by silver coating on the implants [10]. The future research can be on various research niches like surface coating, anti-bacterial properties, and corrosion-resistant technologies associated with stainless steel implants. The reduced level of corrosion can help in less wear and less amount metal content in the blood.

This bibliometric analysis will be a useful platform for future researchers by realizing the top researchers, organizations, and countries involved in research regarding bio-implants. This article is arranged into four sections. The first section is the introduction, followed by the discussion of the methodology by which the research was conducted. The third section deals with results and discussion. The fourth section deals with the conclusion. The following research objectives and research questions were framed for conducting bibliometric analysis systematically.

\subsection{Research Objectives}

a) To consolidate the literature regarding allergy of steel-implants

b) To find out the trends related to research in allergy of steel-implants

\subsection{Research Questions}

a) Who are the active researchers working on the allergy of steel-implants?

b) Which are the main organizations and countries working on the allergy of steel-implants?

c) Which are the main journals related to an allergy to steel-implants?

\section{Research Methodology}

Scopus files had been used for this article. For the article selection, the Boolean used was TITLE-ABS-KEY (Allergy Steel-implants) on 01/03/2021. All the tables in this paper were created by using Microsoft Excel and VOS Viewer. Grammarly was used for spelling and grammar checks. Mendeley was used for article review and 
citation. This paper had been inspired by bibliometric analysis in its presentation style, analysis, and methodology from the works [11]-[17].

\section{Results and discussion}

\subsection{Results}

This first round of search produced an outcome of 83 documents, in four languages, out of which 73 documents were in English. The classification of document categories is shown in Figure 1. For improving the quality of the analysis, we had selected only the peer-reviewed articles and all other documents had not been considered. Thus after using filters "Article" and "English" the second round search produced an outcome of 43 English articles (both open access and others) and had been used to conduct bibliometric analysis and visualization using VOS Viewer. The English research articles in this domain since 1977 had been shown in Figure 2.

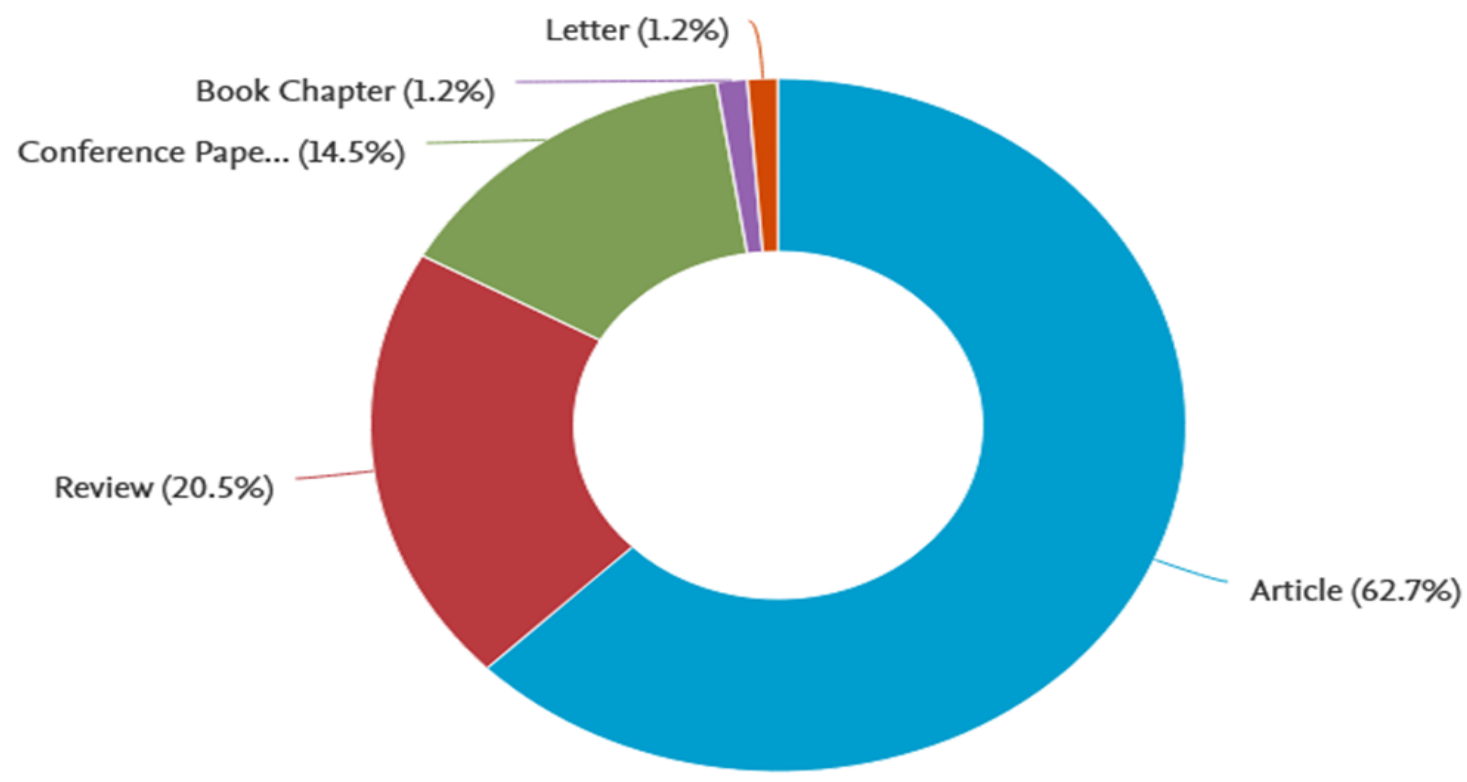

Figure 1: Classification of the documents on "Allergy of Steel-implants", Source: www.scopus.com

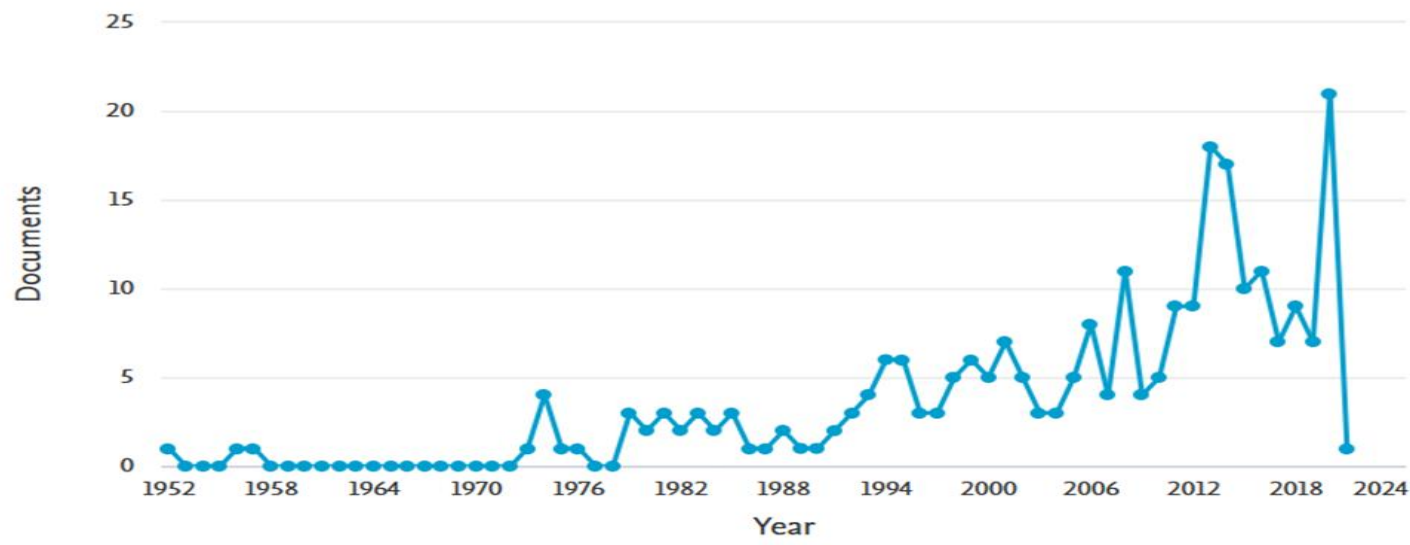

Figure 2: Period wise publication of articles, Source: WWW.scopus.com

Co-authorship analysis of top authors had been shown in figure 3. For a better presentation of the analysis, the parameters used were the minimum number of documents of an author as two and the minimum number of citations of authors as one. This combination plotted the map of 16 authors, in five clusters. The overlay visualization map of co-authorship analysis plotted in Figure 3, points out the major researchers with their strong co-authorship linkages and clusters involved. 

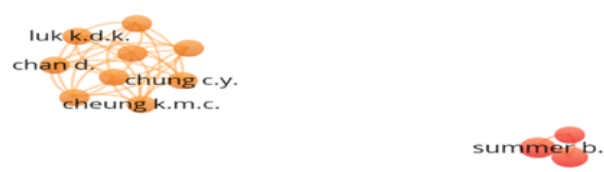

fes vosviewer

goretsky m.j.

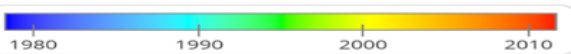

Figure 3: Co-authorship analysis on basis of authors

The citation analysis of top authors had been shown in table 1, along with co-authorship links. For the citation analysis, the parameters used were the minimum number of documents of an author as one and the minimum citations of an author as one.

Table 1: Highlights of most active authors

\begin{tabular}{|c|c|r|r|r|r|}
\hline Description & Authors & Documents & Citations & $\begin{array}{c}\text { Average } \\
\text { citations per } \\
\text { documents }\end{array}$ & $\begin{array}{r}\text { Link } \\
\text { strength }\end{array}$ \\
\hline \multirow{2}{*}{$\begin{array}{c}\text { Leading authors } \\
\text { on "allergy of steel } \\
\text { implants" }\end{array}$} & Summer B & 3 & 104 & 35 & 18 \\
\cline { 2 - 6 } & Thomas P & 3 & 104 & 35 & 18 \\
\hline
\end{tabular}

In Co-occurrence analysis, we had used all keyword analyses, by keeping the minimum number of occurrences of a keyword as 10. This combination plotted the map of 20 thresholds, in two clusters. The overlay visualization of co-occurrence analysis of keywords has been shown in Figure 4.

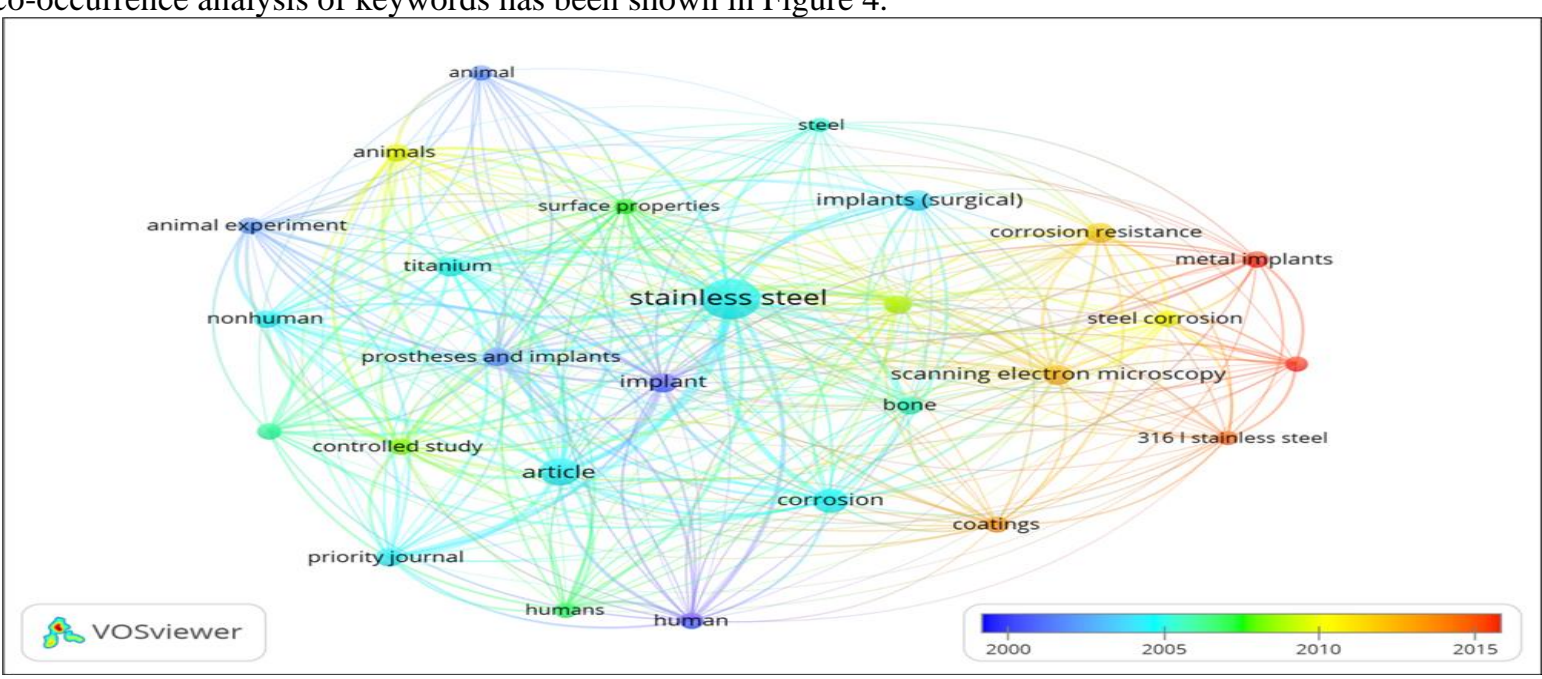

Figure 4: Co-occurrence analysis on basis of all keywords

The leading organizations engaged in research on "Allergy on steel-implants" had been found out by the volume of publications and citation analysis, the parameters used are the minimum number of documents of an organization as one and the minimum number of citations of organizations as one. The leading organization in the research regarding "Allergy on steel-implants", with the highest number of publications and citations, was the University Hospital in Munich(Refer to table 2).

Table 2: Highlights of the most active organization

\begin{tabular}{|c|c|c|c|c|}
\hline Organizations & Country & s Document & Citatio & $\begin{array}{c}\text { Average } \\
\text { Citations } \\
\text { per } \\
\text { document }\end{array}$ \\
\hline University Hospital in Munich & Germany & 3 & 104 & 35 \\
\hline Ludwig- Maximillans University & Germany & 3 & 104 & 35 \\
\hline
\end{tabular}


Co-authorship analysis of the countries engaged in the research on "Allergy of steel-implants" had been shown in Figure 5. The overlay visualization map of co-authorship analysis plotted in Figure 5, points out the main countries with their strong co-authorship linkages and clusters involved.
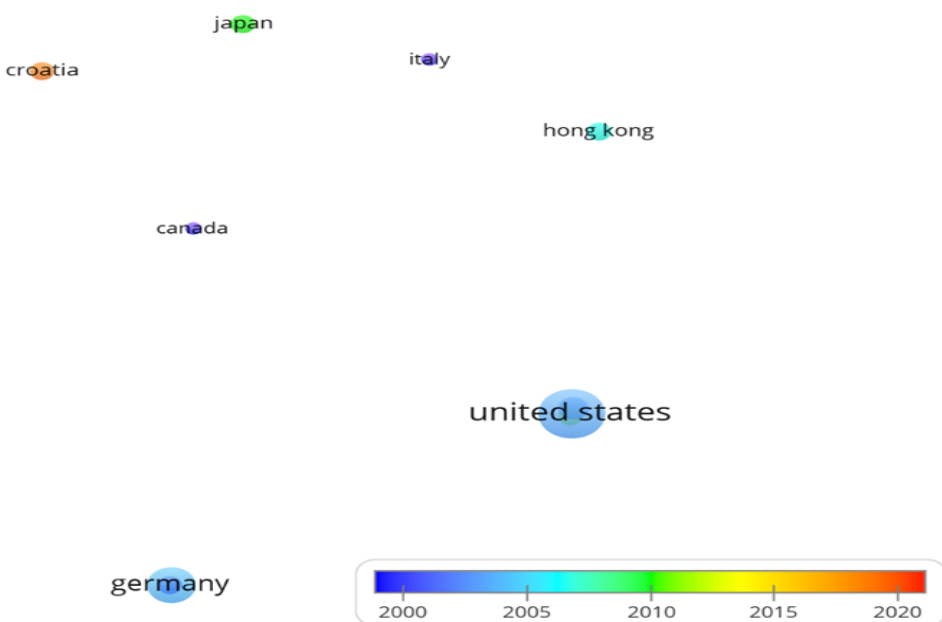

Figure 5: Co-authorship analysis on basis of countries

The citation analysis of top countries had been shown in table 3, along with co-authorship links. For the citation analysis, the parameters used were the minimum number of documents of a country as one and the minimum citations of the country as one.

Table 3: Highlights of Active Countries

\begin{tabular}{|c|c|c|c|c|}
\hline Description & Country & Documen & Citation & Link strength \\
\hline $\begin{array}{l}\text { The country with the } \\
\text { highest publication, } \\
\text { citations, and co-authorship } \\
\text { links }\end{array}$ & $\begin{array}{c}\text { United States of } \\
\text { America }\end{array}$ & & & \\
\hline
\end{tabular}

The most active country in this research domain was the United States of America, with the highest number of publications, citations, and co-authorship links.

Link analysis and citation analysis were used to identify the most active journal in this research domain. We have taken the parameters of the minimum number of documents of a journal as one and the minimum number of citations of a journal as one for the link analysis and citation analysis. Highlights of the most active and relevant journals related to "Allergy of steel-implants" are shown in table 4 . Table 4 shows the journal activity of this research domain through parameters of publication volume, citations, and co-authorship linkages.

Table 4: Analysis of journal activity

\begin{tabular}{|c|c|c|c|c|}
\hline Description & Journal details & Documents & Citations & $\begin{array}{c}\text { Average } \\
\text { citations } \\
\text { per } \\
\text { documents }\end{array}$ \\
\hline $\begin{array}{c}\text { Journal with the } \\
\text { highest publications }\end{array}$ & $\begin{array}{c}\text { Contact } \\
\text { Dermatitis }\end{array}$ & 4 & 131 & 4 \\
\hline $\begin{array}{c}\text { Journal with the } \\
\text { highest citations }\end{array}$ & Injury & 2 & 414 & 0 \\
\hline $\begin{array}{c}\text { Journal with the } \\
\text { highest co-authorship } \\
\text { links }\end{array}$ & $\begin{array}{c}\text { Journal } \\
\text { Paediatric Surgery }\end{array}$ & 2 & 97 & 7 \\
\hline
\end{tabular}

From the above discussion regarding the bibliometric patterns in the research regarding the Allergy of steelimplants, this research had observed a gradual increase in research interest regarding allergy of steel-implants from the starting of the millennium and the momentum is going on positively. This points out the relevance and potential of this research domain (Refer to Figure 2). The most active authors in this research domain were Summer B. and Thomas P.with the highest publication, citations, and co-authorship links (Refer to table 1). The overlay analysis of top countries researching allergy of steel implants indicates that the United States of America was the leading country relating to the highest number of publications, citations, and co-authorship links (Refer to figure 5). The top journals of this research domain were identified as the Contact Dermatitis, Injury, and Journal of Paediatric 
Surgery. From these wide sources of information, researchers can focus on top journals where they can identify the most relevant and highly cited articles regarding allergy teel-implants.

\section{Conclusion}

Allergy of steel-implant was an interesting research domain and the most active journals related to this research domain were the Contact Dermatitis, Injury, and Journal of Paediatric Surgery. The most active country was the United States of America. The leading organization engaged in the research regarding allergy of steel-implants were University Hospital in Munich and Ludwig- Maximilian University of Germany. The most active authors who had made valuable contributions related to the allergy of steel implants were Summer B. and Thomas P. This research domain offers a new avenue for researchers and future research can be on innovations in allergy of steelimplants.

\section{References}

1. A. Fisher, "The safety of stainless steel hip prosthesis in nickel-sensitive individuals," Cutis, vol. 52, no. 4, p. 193, 1993.

2. A. Kolkailah et al., "Bibliometric Analysis of the Top 100 Most Cited Articles in the First 50 Years of Heart Transplantation," Am. J. Cardiol., vol. 123, no. 1, pp. 175-186, 2019.

3. T. Abbas et al., "Sustainability assessment associated with surface roughness and power consumption characteristics in nanofluid MQL-assisted turning of AISI 1045 steel," Int. J. Adv. Manuf. Technol., vol. 105, no. 1-4, pp. 1311-1327, Nov. 2019.

4. X. Tran et al., "The current research landscape of the application of artificial intelligence in managing cerebrovascular and heart diseases: A bibliometric and content analysis,” Int. J. Environ. Res. Public Health, vol. 16, no. 15, 2019.

5. D. Ramteke, A. Balakrishna, V. Kumar, and H. C. Swart, "Luminescence dynamics and investigation of Judd-Ofelt intensity parameters of Sm3+ ion containing glasses," Opt. Mater. (Amst)., vol. 64, pp. 171-178, 2017.

6. G. Singh et al., "Investigations of Machining Characteristics in the Upgraded MQL-Assisted Turning of Pure Titanium Alloys Using Evolutionary Algorithms,” Materials (Basel)., vol. 12, no. 6, Mar. 2019.

7. Shahid et al., "Characteristics of highly cited articles in heart failure: A bibliometric analysis," Future Cardiol., vol. 16, no. 3, pp. 189-197, 2020.

8. J. Liao et al., "The most cited articles in coronary heart disease: A bibliometric analysis between 1970 and 2015," Int. J. Cardiol., vol. 222, pp. 1049-1052, 2016.

9. J. Pugh, W. L. Jaffe, and F. Jaffe, "Corrosion failure in stainless steel implants," Surg. Gynecol. Obstet., vol. 141, no. 2, pp. 199-202, 1975.

10. J. V Linden, S. M. Hopfer, H. R. Gossling, and F. W. Sunderman Jr., "Blood nickel concentrations in patients with stainless-steel hip prostheses," Ann. Clin. Lab. Sci., vol. 15, no. 6, pp. 459-464, 1985.

11. L. Rodríguez-Padial et al., "Trends and Bibliometric Impact of Research Grants of the Spanish Society of Cardiology/Spanish Heart Foundation (2007-2012) [Evolución e impacto bibliométrico de las becas de la Sociedad Española de Cardiología/Fundación Española del Corazón en el periodo 2007-2012]," Rev. Esp. Cardiol., vol. 72, no. 12, pp. 1012-1019, 2019.

12. M. A. Balestriere, K. Schuhladen, K. Herrera Seitz, A. R. Boccaccini, S. M. Cere, and J. Ballarre, "Sol-gel coatings incorporating borosilicate bioactive glass enhance anti corrosive and surface performance of stainless steel implants," J. Electroanal. Chem., vol. 876, 2020.

13. N. Aggarwal, K. Kaur, A. Vasishth, and N. K. Verma, "Structural, optical and magnetic properties of Gadolinium-doped ZnO nanoparticles,” J. Mater. Sci. Mater. Electron., vol. 27, no. 12, pp. 1300613011, 2016.

14. P. Devasconcellos, S. Bose, H. Beyenal, A. Bandyopadhyay, and L. G. Zirkle, "Antimicrobial particulate silver coatings on stainless steel implants for fracture management," Mater. Sci. Eng. C, vol. 32, no. 5, pp. 1112-1120, 2012.

15. P. Priyanka et al., Role of nanogrooves on the performance of ultra-fine grained titanium as a bioimplant. Apple Academic Press, 2014.

16. S. Ullah, S. U. Jan, H. U. Rehman, N. I. Butt, M. A. Rauf, and S. Shah, "Publication trends of Pakistan Heart Journal: A bibliometric study,” Libr. Philos. Pract., vol. 2019, 2019.

17. T. Farhat et al., "Research in congenital heart disease: A comparative bibliometric analysis between developing and developed countries," Pediatr. Cardiol., vol. 34, no. 2, pp. 375-382, 2013. 